\title{
The Factors Affecting Development of Marketing Capability of Collegiate Sport
}

\author{
${ }^{1}$ Rasoul Tarighi ${ }^{*}{ }^{1}$ Mehrzad Hamidi \\ ${ }^{1}$ Department of Sport Management, Faculty of Sport Sciences, University of Tehran, Tehran, Iran.
}

\begin{abstract}
Background. Now one of the necessary capabilities, to succeed in the field of competition is having knowledge and marketing skills in economic institutions. Objectives. The goal of this study was Factors affecting development of marketing capability of collegiate sport. Methods. This study is correlating, and, in view of objective, current research is practical. Populations consist of 5 groups which involve previous and present executive committee, administers of provincial committees, experts and employers of National University Sport Federation, headmen and experts of Sport administration and Sports directors of further education section of universities, contain governmental universities, Azad, Payam Noor, Practical and scientific, Hygiene and Therapy and Medical Science universities, and some members of the faculty of universities. In regard to limitation of populations, sampling method is all-counting. Results. The result showed that the totality of confirmatory factor analysis model have necessary fitting $(\mathrm{GFI}=0.90, \mathrm{RMSEA}=0.045, \mathrm{p}<0.001)$. The Results Showed that factor's include management capability $(\mathrm{T}=16.06)$, marketing staff $(\mathrm{T}=14.81)$, marketing strategy $(\mathrm{T}=14.57)$, marketing information system $(\mathrm{T}=12.57)$, marketing organization $(\mathrm{T}=12.56)$, and branding capability $(\mathrm{T}=12.17)$, with significant Priorities respectively, were effective factor's on marketing capability of National University Sports Federation of Islamic Republic of Iran. Also, marketing capability $(\mathrm{T}=11.10)$ has a positive and significant effect on marketing performance of National University Sports Federation. Conclusion. According to obtained results from Opinions of university sport specialists and experts, it seems that managers of university sport should have Pay more attention to identified factors of university sport development that Which ranked respectively had the highest impact factor (Such as management capability, marketing staff and marketing strategy).
\end{abstract}

KEY WORDS: Collegiate Sport, Sport Marketing, Marketing Strategy, Branding Capability.

\section{INTRODUCTION}

Nowadays, professional sports have been changed into great trades and sport managers benefit from concepts of marketing and customer's demand (1). Moreover, sport organizations are subject to environmental and global changes and they are challenged with specific issues (2). Results of research suggest that in the second half of $20^{\text {th }}$ century, process system was formed in such a way that it led to transfer of economy from industrialism to services (3). Increasing demand of companies for physical activities and sports has caused the growth and development of such activities throughout the world such that different

*. Corresponding Author:

Rasoul Tarighi

E-mail: rasoul.tarighi@ut.ac.ir 
movements, organizations and institutions have been created to react to such demand. This shows the importance of sport in today's communities for improvement and promotion of public health and pleasure as well as international achievements (4). While sport organizations have gained considerable incomes in recent years, current costs of such sectors have incrementally grown. In NBA league, mean salary and wage is above 4 million dollar annually (5). In addition, 1 million dollar should be spent for establishment of a new stadium for some NFL teams (6). Therefore, managers of professional and collegiate sport organizations should manage effectively challenges such as heavy costs, competitive market, fans' dissatisfaction and their disconnection as well as explosive growth of modern technologies so as to survive in sport business setting (7). In addition to strong and effective use of marketing, sport organizations should identify their potential clients firstly and then provide a product for meeting requirements of the client as well as for developing strategies of achievement, price and certain product (8). Gundogan (1996) studied collegiate sport marketing and stated that there is an increasing growth in the number of full time personnel, written programs of marketing as well as sport marketing budget showing the increasing importance of sport marketing in colleges (8). In addition, it is stated that marketing program allows the organization to evaluate correctly the requirements of marketing budget and to identify the amount of revenue obtained by sport marketing (7). Pine (2010) concluded that universities should pay attention to cancellation of academic tuitions as a subsidy for students and their encouragement (9). As mentioned earlier, many students are studying scientifically and academically sport industry as well as sport marketing throughout the world in higher education centers (10). Moreover, financial circulation of sport industry of the world has grown considerably within a decade and several thousands of people are working directly and indirectly in this industry as one of the best industries (11). Therefore, sport organizations are seeking development of their marketing activities. Collegiate sport is one part of sport industry and pays special attention to marketing programs. Gundogan (1996) evaluated sport marketing of collegiate basketball competitions and referred to the increasing importance of sport marketing in collegiate sport (8).

Furthermore, several researches show that marketing of collegiate sports has grown significantly. Branvold and Bowers (1992) studied the use of marketing activities in collegiate baseball and they showed that the use of marketing programs was very effective in the increase of audiences and revenue of colleges (12). The revenue of sport support in league one of national collegiate athletic association of America increased by $79 \%$ from 1997 to 2001 and it reached from 760000 dollar to 1.38 million dollar per institute (13). It is found that different sport organizations like CII, professional teams and collegiate athletic association in Canada are seeking different marketing goals depending on the given conditions. They explained that professional teams emphasized on the value of entertainment to settle stresses and social team orientation whereas CII focused on team marketing. In addition, Canada collegiate athletic association considered proper sport places for athletes and team quality as the important factors in reaching marketing goals (8). With the growth and development of sport in Iran, the growth of collegiate sport has been seen such that national federation of collegiate sports was established in 2005 and started its activity officially. The federation increased the development of collegiate sport from national level to provincial level by conducting national Olympiads of collegiate sport, participation of teams of macro sectors of ministry of science and higher education, dispatching of national teams of collegiate sport for continental and international competitions as well as formation of provincial boards. The increasing development of the programs and activities of the federation is evident in all collegiate sport departments. It is noteworthy that such federation like other sport organizations obtains its budget mostly from governmental sources. This is why marketing programs and activities have been paid less attention in Iran (14). In fact, sport marketing in Iran depends on and is limited to the presence of government in professional sports and championships such that production and selling 
of sport products, selling tickets of different competitions, insufficient support of financial sponsors from some sport teams could not reduce the intense dependency of professional sport on the government. It seems that to solve such problems, researchers, experts and experienced managers should collaborate with each other to manage financial circulation and staffs by studying and analyzing complexity governing the sport market of Iran. That is why many sport organizations used marketing processes to conduct their missions and reach their goals. It is very important for national federation of collegiate sports, as a national collegiate institution, to identify factors affecting development of sport marketing and thus to reach its goals. Regarding the importance of marketing in supply of financial sources and government's policy for privatization in the third and fourth development programs, collegiate championships will reach more valuable results such as increase of national pride and international promotion. Moreover, carrying out present research is felt more tangible due to the coordination and synergy of championship activities in areas related to higher education with national federation of collegiate sports. As mentioned earlier, creation of capacity and various financial foundations, marketing and revenue of national federation of collegiate sports have all been considered as the second strategy in the federation (15). Regarding the importance of marketing activities in universities especially in national federation of collegiate sports, the following questions resulted: what are the factors affecting the development of marketing capability of national federation of collegiate sports in Iran, how is the effectiveness of such factors prioritized and what is the suggested model for the federation?

\section{MATERIALS AND METHODS}

Participants. The statistical population of the research consists of five groups. The groups include the ex- and current management board of national federation of collegiate sports $(n=14)$, heads of provincial boards of national federation of collegiate sports $(n=31)$, experts and staffs of national federation of collegiate sports $(n=5)$, managers and experts of general offices of physical education in higher education sectors $(n=160)$ and faculty members of sport management who were aware of federation affairs $(n=20)$. Regarding the small size of statistical population in the present research, the sample was equal to the statistical population and the total number of population was used in sampling. A field research was used to collect information.

Instrument. The researcher-made questionnaire was used to collect information. Its validity was determined by ten professors of sport management and its reliability was determined by Cronbach's alpha test. The instrument was derived from items of previous research on marketing. It includes 8 main factors and 40 items and it has been designed based on five-point Likert scale. The amount of Cronbach's alpha coefficient done on 30 questionnaires in preliminary study showed that Cronbach's alpha coefficient of all dimensions was above 0.8 and total alpha coefficient was 0.98 showing proper reliability of the questionnaire.

Statistical analysis. In descriptive section, frequency table, mean and standard deviation were used to analyze statistically the research. Moreover, SPSS Version 20 was applied for tests. In inferential section, confirmatory factor analysis was used to model Lisrel.

\section{RESULTS}

A total number of $46 \%$ of respondents ( $n=93$ ) had bachelor degree, $34.7 \%(n=70)$ had MSc degrees and $11.4 \%(\mathrm{n}=23)$ had $\mathrm{PhD}$. In addition, $84.2 \%(n=170)$ had academic degree of physical education and $15.8 \%(n=32)$ had degrees other than physical education. Descriptive statistics results indicated that $47.5 \%$ of respondents $(n=96)$ were managers, 34.2\% $(n=69)$ were experts and $18.3 \% \quad(n=37)$ were faculty members. Based on results obtained from inferential statistics, $t$ value of all relations of the conceptual model is above 2 . Therefore, it can be concluded that all relations of the conceptual model are statistically significant. Moreover, inferential statistics results showed that components of marketing organization, marketing information system, marketing strategy, marketing staffs, branding capability as well as management capability of national federation of collegiate sports had a positive and 
significant effect on marketing capability and marketing performance.

Based on structural equity modeling, factors such as marketing organization $(\beta=0.76, \mathrm{~T}=$ 12.56), marketing information system $(\beta=0.76$, $\mathrm{T}=12.57)$, marketing strategy $(\beta=0.84, \mathrm{~T}=$ 14.57), marketing staffs $(\beta=0.85, \mathrm{~T}=14.81)$, branding capability $(\beta=0.75, \mathrm{~T}=12.17)$ and management capability $(\beta=0.89, \mathrm{~T}=16.06)$ are effective on the development of marketing capability of Iran collegiate sport. Furthermore, based on results, marketing capability $(\beta=0.92$, $\mathrm{T}=11.10)$ is effective on marketing performance of collegiate sport (Figure 1).

Table 1. The main factors and items of factors affecting the development of marketing in collegiate sport in Iran.

\begin{tabular}{|c|c|c|c|c|c|c|}
\hline Factors & No. & Items & Mean & $\begin{array}{l}\text { Factorial } \\
\text { load }\end{array}$ & $\begin{array}{l}\text { Standard } \\
\text { deviation }\end{array}$ & $\begin{array}{c}\text { T- } \\
\text { value }\end{array}$ \\
\hline \multirow{4}{*}{$\begin{array}{l}\text { Marketing } \\
\text { organization }\end{array}$} & 1 & $\begin{array}{l}\text { There should be a marketing organization in federation } \\
\text { of collegiate sports }\end{array}$ & 3.40 & 0.79 & 0.77 & 13.03 \\
\hline & 2 & $\begin{array}{l}\text { Marketing organization of collegiate sports federation } \\
\text { should have a proper place }\end{array}$ & 3.38 & 0.77 & 0.71 & 12.38 \\
\hline & 3 & $\begin{array}{l}\text { Marketing organization of collegiate sports federation } \\
\text { should have good coordination with other departments } \\
\text { of federation }\end{array}$ & 3.32 & 0.80 & 0.79 & 13.23 \\
\hline & 4 & $\begin{array}{l}\text { Marketing organization of collegiate sports federation } \\
\text { should identify its stakeholders (students, staffs, } \\
\text { supporters, sport boards, upstream organizations) }\end{array}$ & 3.38 & 0.68 & 0.71 & 10.60 \\
\hline \multirow{4}{*}{$\begin{array}{l}\text { Marketing } \\
\text { information } \\
\text { system }\end{array}$} & 5 & $\begin{array}{l}\text { The federation should have marketing information } \\
\text { system }\end{array}$ & 3.31 & 0.81 & 0.77 & 13.35 \\
\hline & 6 & $\begin{array}{l}\text { Marketing information system should be available in } \\
\text { the federation }\end{array}$ & 2.99 & 0.66 & 0.97 & 10.15 \\
\hline & 7 & Marketing information system should be practical & 3.16 & 0.81 & 0.82 & 13.32 \\
\hline & 8 & $\begin{array}{l}\text { Federation should conduct marketing researches to } \\
\text { measure clients' satisfaction }\end{array}$ & 3.14 & 0.68 & 0.76 & 10.56 \\
\hline \multirow{5}{*}{$\begin{array}{l}\text { Marketing } \\
\text { strategy }\end{array}$} & 9 & $\begin{array}{l}\text { The importance of marketing should be identified in the } \\
\text { federation }\end{array}$ & 3.20 & 0.69 & 0.81 & 10.82 \\
\hline & 10 & $\begin{array}{l}\text { Federation managers should be committed to marketing } \\
\text { activities }\end{array}$ & 3.15 & 0.72 & 0.81 & 11.45 \\
\hline & 11 & There should be marketing strategy in federation & 3.18 & 0.77 & 0.78 & 12.56 \\
\hline & 12 & $\begin{array}{l}\text { Federation should provide a website to communicate } \\
\text { with clients and stakeholders }\end{array}$ & 3.42 & 0.70 & 0.85 & 11.05 \\
\hline & 13 & $\begin{array}{l}\text { Strategies of improvements and increase of clients' } \\
\text { satisfaction should be prioritized in the federation }\end{array}$ & 3.24 & 0.76 & 0.85 & 12.36 \\
\hline \multirow{6}{*}{ Marketing staffs } & 14 & Marketing staffs should have enough experiences & 3.41 & 0.76 & 0.68 & 12.42 \\
\hline & 15 & Marketing staffs should have marketing thinking & 3.35 & 0.71 & 0.74 & 11.20 \\
\hline & 16 & Marketing staffs should be well trained & 3.37 & 0.75 & 0.76 & 12.07 \\
\hline & 17 & $\begin{array}{l}\text { Marketing staffs should respond rapidly to variable } \\
\text { requirements of clients }\end{array}$ & 3.19 & 0.74 & 0.83 & 11.82 \\
\hline & 18 & $\begin{array}{l}\text { Marketing staffs should participate in federation's } \\
\text { decisions and planning }\end{array}$ & 2.95 & 0.69 & 1.06 & 10.83 \\
\hline & 19 & $\begin{array}{l}\text { Marketing staffs should be aware of sport demands of } \\
\text { students }\end{array}$ & 3.23 & 0.77 & 0.76 & 12.63 \\
\hline \multirow{5}{*}{$\begin{array}{l}\text { Branding } \\
\text { capability }\end{array}$} & 20 & $\begin{array}{l}\text { The federation brand should be simple and identifiable } \\
\text { for the public }\end{array}$ & 3.27 & 0.77 & 0.82 & 12.45 \\
\hline & 21 & $\begin{array}{l}\text { Branding should be one of operational programs of the } \\
\text { federation }\end{array}$ & 2.98 & 0.72 & 0.87 & 11.39 \\
\hline & 22 & $\begin{array}{l}\text { The simple concept of brand causes better } \\
\text { communication of federation with clients (students, } \\
\text { university staffs and supporters) }\end{array}$ & 3.13 & 0.85 & 0.73 & 14.64 \\
\hline & 23 & $\begin{array}{l}\text { Federation managers should pay more attention to } \\
\text { threats of federation brand }\end{array}$ & 3.07 & 0.83 & 0.84 & 13.95 \\
\hline & 24 & $\begin{array}{l}\text { Federation should employ expert staffs to support the } \\
\text { brand }\end{array}$ & 3.24 & 0.66 & 0.79 & 10.12 \\
\hline
\end{tabular}


Table 1. Continued

\begin{tabular}{|c|c|c|c|c|c|c|}
\hline Factors & No. & Mean & $\begin{array}{c}\text { Factorial } \\
\text { load }\end{array}$ & $\begin{array}{l}\text { Standard } \\
\text { deviation }\end{array}$ & & -value \\
\hline \multirow{6}{*}{$\begin{array}{l}\text { Management } \\
\text { capability }\end{array}$} & 25 & $\begin{array}{l}\text { Marketing management should have essential specialty } \\
\text { in the federation }\end{array}$ & 3.34 & 0.70 & 0.80 & 11.15 \\
\hline & 26 & $\begin{array}{l}\text { Marketing management should have essential capability } \\
\text { in the federation }\end{array}$ & 3.31 & 0.84 & 0.76 & 14.52 \\
\hline & 27 & $\begin{array}{l}\text { Federation managers should be able to implement } \\
\text { rapidly marketing strategies }\end{array}$ & 3.30 & 0.71 & 0.77 & 11.45 \\
\hline & 28 & $\begin{array}{l}\text { Supply chain of facilities and financial source of } \\
\text { federation should be managed favorably }\end{array}$ & 3.30 & 0.84 & 0.80 & 14.38 \\
\hline & 29 & $\begin{array}{l}\text { Federation managers should manage processes such that } \\
\text { federation costs are saved }\end{array}$ & 3.31 & 0.56 & 0.79 & 8.48 \\
\hline & 30 & $\begin{array}{l}\text { Federation managers should be able to offer basic } \\
\text { solutions for solving clients' problems (students, staffs, } \\
\text { supporters) }\end{array}$ & 3.28 & 0.70 & 0.75 & 11.06 \\
\hline \multirow{4}{*}{$\begin{array}{l}\text { Marketing } \\
\text { capability }\end{array}$} & 31 & $\begin{array}{l}\text { Distribution channels of sport services should be } \\
\text { favorable }\end{array}$ & 3.37 & 0.74 & 0.67 & 11.77 \\
\hline & 32 & $\begin{array}{l}\text { Developmental and promotional activities of sport } \\
\text { services should be favorable }\end{array}$ & 3.35 & 0.82 & 0.78 & 13.84 \\
\hline & 33 & Sport activities and services should be well priced & 3.15 & 0.75 & 0.68 & 12.07 \\
\hline & 34 & The federation should attract supporters & 3.45 & 0.74 & 0.81 & 11.85 \\
\hline \multirow{6}{*}{$\begin{array}{l}\text { Marketing } \\
\text { performance }\end{array}$} & 35 & $\begin{array}{l}\text { Students and collegiate experts should benefit from } \\
\text { sport services }\end{array}$ & 3.40 & 0.76 & 0.68 & 12.38 \\
\hline & 36 & $\begin{array}{l}\text { Federation should be able to attract new clients } \\
\text { (students, university staffs, supporters) }\end{array}$ & 3.36 & 0.86 & 0.76 & 15.19 \\
\hline & 37 & $\begin{array}{l}\text { Federation should have a large contribution in sport } \\
\text { services for students and university staffs compared to } \\
\text { other sectors }\end{array}$ & 3.27 & 0.66 & 0.82 & 10.28 \\
\hline & 38 & Federation should consider its competitive advantages & 3.24 & 0.64 & 0.72 & 9.97 \\
\hline & 39 & $\begin{array}{l}\text { Federation should prepare new ideas and programs to } \\
\text { help students' sport }\end{array}$ & 3.49 & 0.76 & 0.67 & 12.58 \\
\hline & 40 & $\begin{array}{l}\text { Federation should consider clients' } \\
\text { (students, university staffs, supporters) }\end{array}$ & 3.41 & 0.82 & 0.72 & 14.01 \\
\hline
\end{tabular}

Fitness indices obtained for the research model have been mentioned in following table. If the value of this index is below 0.05 , model fitness will be good. Regarding the fact that this index is 0.045 , the model's fitness is favorable. Regarding RMR index, the closer the criterion is to zero, the higher the model's goodness of fit. RMR output of the model is 0.018 and it has a favorable goodness. The acceptable value of GFI and AGFI is above 0.9. Therefore, the above model has a favorable goodness (Table 2).

Table 2. The obtained fitting indicators for the model

\begin{tabular}{ccc}
\hline Index Name & Study Model & Result \\
RMSEA & $0 / 45$ & Model Favorable Fitting \\
$\chi^{2} /$ df & $2 / 44$ & Model Favorable Fitting \\
GFI & $0 / 90$ & Model Favorable Fitting \\
AGFI & $0 / 86$ & Model Favorable Fitting \\
RMR & $0 / 18$ & Model Favorable Fitting \\
NFI & $0 / 97$ & Model Favorable Fitting \\
CFI & $0 / 98$ & Model Favorable Fitting \\
\hline
\end{tabular}




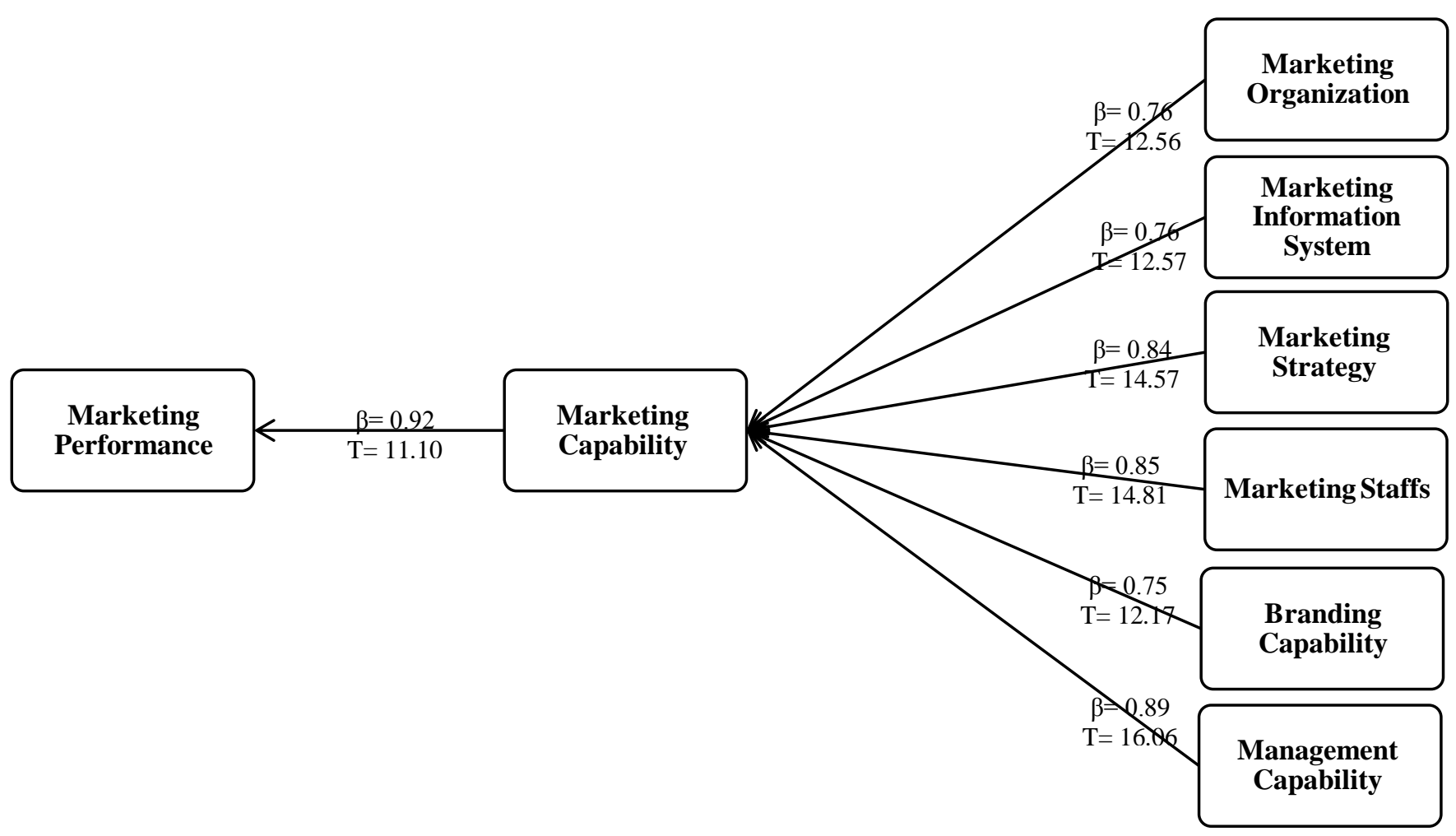

Figure 1. Structural model, values of $\mathrm{T}$ and factor weight of the main factors of research

Based on the result obtained it can be concluded that the current study conceptual model enjoys a suitable fitting, by using the standard coefficients for each of the variables we can extract the structural equations. The structural equation of marketing capability variable is defined in the following:

Marketing Capability $=(0.76 \times$ Marketing Organization $)+(0.76 \times$ Marketing Information System $)+(0.84 \times$ Marketing Strategy $)+(0.85 \times$ Marketing Personnel $)+(0.75 \times$ Branding Capability $)+(0.89 \times$ Management Capability $)$

The structural equation of marketing performance variable is defined in the following.

\section{Marketing Performance $=0.92 \times$ Marketing Capability}

\section{DISCUSSION}

The present research aims to evaluate factors affecting development of marketing capability of collegiate sport in Iran. Results showed that variables of management capability, marketing staffs, marketing strategy, marketing information system, marketing organization and branding capability were effective on marketing capability of collegiate sport, respectively. In addition, marketing capability has a positive and significant effect on marketing performance of collegiate sport.

Results indicate that marketing organization is one of the factors affecting marketing development of national federation of collegiate sports. Concerning the obtained results, national federation of collegiate sports should include marketing organization with proper place. Such organization should have a good harmony with other departments of federation. Furthermore, such organization should identify stakeholders (supporters, students and university staffs). In this line, Yoon and Kang (2005) defined marketing organization as one of the factors affecting servicing industries (16). 
Marketing information system is another factor affecting marketing development of national federation of collegiate sports. Regarding the obtained results, federation should have marketing information system. Furthermore, marketing information system should be practical and available as well as it should conduct marketing research to evaluate costumers' satisfaction. According to results obtained from the present research, Asikhia (2010) believes that marketing information system is one of the factors affecting increase of marketing capability of small and medium scale enterprises in Nigeria (17). Rahimah, Astuti, and Hamid (2014) concluded that the best solution for solving problems of small and medium scale enterprises in Indonesia is to design a proper marketing information system (18). Yoon and Kang (2005) outlined marketing information system as one of the factors affecting marketing development of servicing companies in South Korea (16).

Marketing strategy is another factor affecting marketing development of national federation of collegiate sports. Results suggest that federation should have proper marketing strategy. Federation managers should perceive marketing importance and commit to marketing activities. On the other hand, federation ought to have a proper website to communicate with clients and stakeholders. Lozano and Vallés (2007) believe that strategy (as a basic for realization of goals, prediction of environmental changes, responsibility and commitment) is one of the factors affecting marketing development (19).

Marketing staffs is another factor affecting marketing development of national federation of collegiate sports. Concerning results, marketing staffs should have enough experience; marketing thinking as well as they should be well-trained. Marketing staffs should participate in planning and decision of federation, they should be aware of sport requirements of students and they should be able to respond rapidly to clients' variable requirements. Yoon and Kang (2005) believe that marketing staff is considered as a factor affecting development of marketing capability (16).

Results show that branding capability is another factor affecting marketing development of national federation of collegiate sports.
Concerning obtained results, federation brand should be simple and identifiable for the public and it leads to better communication of clients (supporters, staffs and students) with the federation. In addition, federation should use experienced staffs to support its brand. Fleck, Michel, and Zeitoun (2014) stated that when the message of brand causes doubts in the mind of consumer, consumer cannot trust in the company and its brand (20). Wong and Merrilees (2008) studied advantages of directional brand performance and concluded that there was a positive and strong relationship between brand orientation and brand performance (21).

According to Gladden, Irwin, and Sutton (2001) companies help their teams by maintaining their brand equity as well as support of followers, special companies and journals (22). They also suggested that to challenge the reduction of teams' followers, team brand should be strengthened in minds of consumers by strengthening brand, making strong relationship with followers via correct public communication management (23). In another research, Ross (2006) stated that direct control of factors affecting a brand has a direct effect on knowledge of consumer about the brand and related factors (24). Merrilees, Rundle-Thiele, and Lye (2011) concluded that branding and innovation are two key components in development of marketing capability (25). In addition, Kazybaeva and Satkalieva (2014) stated that the picture of brand, the quality of relationship with customers, the increasing number of loyal customers as well as the increasing level of customer's loyalty were obtained by the increasing brand equity (26).

Marketing management capability is another factor affecting marketing development of national federation of collegiate sports. Results indicate that federation managers should have essential specialty and capability to implement marketing strategies. Furthermore, managers should manage favorably processes, supply chain of facilities and financial sources of federation and they should save federation's costs. On the other hand, federation managers should find solutions for solving customers' problems (students, staffs and supporters). Lozano and Vallés (2007) stated that management style includes a real model of 
managers' operations, it determines priorities in organization and it has significant effect on organizational performance, thus it is one of intra-organizational factors for marketing development (19). Pitts and Stotlar (2013) studied management capability as one of the factors which is important in growth of marketing of sport organizations (27).

Results indicated that marketing capability of national federation of collegiate sports has a positive and significant effect on marketing performance. Results obtained from marketing capability showed that federation's sport service distribution channels should be capable and they should develop and promote sport services favorably. Furthermore, pricing of sport activities and services should be done correctly and federation should be capable of customers' attraction. Results obtained from marketing performance of the federation showed that the federation should be able to reach new customers (students, staffs and supporters) and it has a great contribution in providing sport services to students and staffs compared to other sectors. Federation should consider its competitive advantages. Moreover, it should present new ideas and programs to help student's sport and it should pay attention to customers' suggestions (students, staffs, supporters).

\section{CONCLUSION}

Concerning results obtained from present research, it can be concluded that six factors of marketing organization, marketing information system, marketing strategy, branding capability and management capability play significant role in development of sport marketing of national federation of collegiate sport. Therefore, national federation of collegiate sport is responsible for all sport activities and events in Iranian universities, thus the federation should pay attention as well as invest on such factors. Therefore, the federation should increase its marketing capability to reach many achievements by activities related to sport marketing such as revenue creation, promotion, attraction of sponsors for holding sport events and satisfaction of customers' needs. Thus, sport will be strengthening in universities and institutes of higher education. Consequently, Iranian universities will face a healthy and happy space with healthy students. In addition, by holding student's different sport events regionally and throughout the country, national federation of collegiate sport can be a proper path for manifestation of elite people in order to participate in international student sport events as well as to increase national pride.

\section{APPLICABLE REMARKS}

- Application of marketing activities causes marketing organization of national federation of collegiate sport to have a good harmony with other departments of the federation and stakeholders (supporters, students and staffs). It also makes marketing information system easy to access and thus it can perform marketing research for measuring customers' satisfaction.

- Use of marketing tools allows the federation managers to perceive marketing and to provide a proper website for better communication with customers and stakeholders. Furthermore, the federation should attract experienced staffs with marketing thinking and they should be well-trained.

- Implementation of marketing activities in national federation of collegiate sport causes better communication of the federation brand with customers (supporters, staffs and students). Moreover, managers are encouraged to acquire marketing knowledge, to implement marketing strategies of the federation and to manage favorably financial sources. 


\section{REFERENCES}

1. Sajjadi SN, Rajabi H, Abed Lati M, Tarighi R. Identifying Factors Affecting Brand Equity of Professional Football Teams The Case Study of Esteghlal Tehran Football Club. Sport Management Studies. 2016;8(39):87102 [Article in Farsi].

2. Sajjadi SN, Rajabi H, Abed Lati M, Tarighi R. A Study of the Factors Influencing Brand Equity of Tehran Persepolis Football Club. New Trends in Sport Management. 2014;1(3):43-52 [Article in Farsi].

3. Rajabi H, Tarighi R, Mizany M. The Study of Customer experiences and satisfaction of service in Aquatic sports clubs. Applied Research of Sport Management 2016;4(15):67-78 [Article in Farsi].

4. Brown M, Nagel M, editors. The Size of the Sport Industry in the United States. The 10th European sport management congress; 2002 4-7 September; Jyvaskyla, Finland: the European association for sport management (EASM).

5. Dupree D. USA Today salary database 2008 [Available from: http://content.usatoday.com/sports/basketball/NBA/salaries/default.aspx.

6. Riper T. Here come the super-stadiums: Forbes; 2008 [Available from: http://www.forbes.com/2008/03/31/sports-stadiums-yankees-bizsports_cx_tvr_0331stadiums.html.

7. Gladden J, Sutton W. Marketing principles applied to sport management. Principles and practices of sport management. 2009:42-59.

8. Gundogan N. Marketing effectiveness and promotional strategies in National Collegiate Athletic Association Division I basketball programs: Temple University; 1996.

9. Pine N. The Role of Athletics in the Academy: An Alternative Approach to Financial Investment. Journal of Sport and Social Issues. 2010;34(4):475-80.

10. Pitts BG. Teaching sport marketing: Notes from the trenches. Sport Marketing Quarterly. 2002;11(4):201-6.

11. Westerbeek HM, Shilbury D. A Conceptual Model for Sport Services Marketing Research: Integrating Quality, Value and Satisfaction. International Journal of Sports Marketing and Sponsorship. 2003;5(1):3-23.

12. Branvold SE, Bowers R. The use of promotions in college baseball. Sport Marketing Quarterly. 1992;1(1):19-24.

13. Tomasini N, Frye C, Stotlar D. National collegiate athletic association corporate sponsor objectives: are there differences between divisions IA, I-AA, and I-AAA? Sport Marketing Quarterly. 2004;13(4).

14. Tarighi R, Hamidi M, Rajabi H. Identifying Effective Factors in Development of Sport Marketing in University Sport of I.R. Iran. Sport Management Studies. 2017;8(40):113-30 [Article in Farsi].

15. Tarighi R, Hamidi M, Rajabi H. Designing Sport Marketing Model of National University Sport Federation of Ir. Iran. Journal of Research on University Sport. 2014;2(5):15-30 [Article in Farsi].

16. Yoon S-J, Kang J-W. Validation of Marketing Performance Model for Service Industries in Korea. Services Marketing Quarterly. 2005;26(4):57-76.

17. Asikhia O. Customer orientation and firm performance among Nigerian small and medium scale businesses. International Journal of Marketing Studies. 2010;2(1):197.

18. Rahimah A, Astuti ES, Hamid D. Analysis and Design Marketing Information System to Improve Competitive Advantage in East Java SMEs. Analysis. 2014;4(1):1-6.

19. Lozano M, Vallés J. An analysis of the implementation of an environmental management system in a local public administration. Journal of Environmental Management. 2007;82(4):495-511.

20. Fleck N, Michel G, Zeitoun V. Brand Personification through the Use of Spokespeople: An Exploratory Study of Ordinary Employees, CEOs, and Celebrities Featured in Advertising. Psychology \& Marketing. 2014;31(1):8492.

21. Wong HY, Merrilees B. The performance benefits of being brand-orientated. Journal of Product \& Brand Management. 2008;17(6):372-83.

22. Gladden JM, Irwin RL, Sutton WA. Managing North American major professional sport teams in the new millennium: A focus on building brand equity. Journal of Sport Management. 2001;15(4):297-317.

23. Gladden JM, Milne GR, Sutton WA. A conceptual framework for assessing brand equity in Division I college athletics. Journal of sport management. 1998;12(1):1-19.

24. Ross SD. A conceptual framework for understanding spectator-based brand equity. Journal of Sport Management. 2006;20(1):22-38.

25. Merrilees B, Rundle-Thiele S, Lye A. Marketing capabilities: Antecedents and implications for B2B SME performance. Industrial Marketing Management. 2011;40(3):368-75.

26. Kazybaeva AM, Satkalieva TS. Forming the strategy and long-term marketing program for brand management. Life Science Journal. 2014(6):227-33.

27. Pitts BG, Stotlar DK. Fundamentals of Sport Marketing. 4th ed: Fitness Information Technology; 2013. 470 p. 